\title{
Secretions of stingless bees: the Dufour glands of some Frieseomelitta species (Apidae, Meliponinae)
}

\author{
Eda Flávia L.R.A. PATRICIO ${ }^{\mathrm{a}}$, Leopoldo CRUZ LÓPEZ ${ }^{\mathrm{b}, \mathrm{c}}$, Roland MAILE ${ }^{\mathrm{b}}$, \\ E. David MORGAN ${ }^{\mathrm{b} *}$

\begin{abstract}
a Laboratório de Abelhas, Instituto de Biociências, Universidade de Saõ Paulo, 05508-900 Saõ Paulo SP, Brasil
b Chemical Ecology Group, Lennard-Jones Laboratory, School of Chemistry and Physics, Keele University, Staffs., ST5 5BG, UK

c Present address: El Colegio de la Frontera Sur, Carretera Antiguo Aeropuerto Km. 2.5, Tapachula, Chiapas,
\end{abstract} \\ CP 30700, AP 36, Mexico
}

(Received 14 June 2002; revised 25 November 2002; accepted 12 December 2002)

\begin{abstract}
The first recorded analyses of meliponine bee Dufour gland secretions by gas chromatographicmass spectrometry on three species of Frieseomelitta showed these glands contain a mixture of oxygenated compounds and terpenoids with some hydrocarbons. In $F$. varia the major substances are eicosenal, 1-eicosenol and 2-pentadecanone. In $F$. sylvestrii they are pentacosene, nonadecanal and heptacosene. $F$. silvestrii languida, with the largest glands and the most complex mixture, has geranylfarnesol, followed by 1-tetradecanol and tetradecanal, making it quite different from $F$. silvestrii.
\end{abstract}

Frieseomelitta sylvestrii / Frieseomelitta varia / Frieseomelitta sylvestrii languida / geranylfarnesol

\section{INTRODUCTION}

The subfamily Meliponinae Ashmead 1899 , or stingless bees, is divided into two tribes, the neotropical Meliponini Handlirsh 1924, and the pantropical Trigonini Moure 1946. The Dufour gland, an accessory gland of the venom apparatus, is generally accepted as present in the queens and workers of all aculeate Hymenoptera. However, Kerr and de Lello (1962) and de Lello (1976) examined 26 species of Trigonini and about 15 species of Meliponini. They found that the Dufour gland is normally present in workers of all Apoidea, but while the gland was present in all the queens they were able to examine, it was absent or vestigial in workers of all Melipona species. Likewise, it was absent from workers of Trigona, Oxytrigona,
Cephalotrigona, Scaptotrigona, Partamona and Lestrimelitta.

The secretion of this gland has been found to modulate the behavior of some bee species, particularly solitary bees (Hefetz, 1987). Isoprenoid esters found in the Dufour gland of Colletes and Andrena might be employed to line the cells and if mixed with other odours, to mark the nest (Bergström and Tengö, 1974; Tengö and Bergström, 1975). The most important components of the Dufour gland of many Colletidae and Halictidae bees are macrocyclic lactones used to line the nest in soil (Hefetz et al., 1978, 1979). Terpenoid esters were found in the Dufour gland secretion of Andrena haemorrhoa and other bees of this group and in Calliopus andreniformis (Andrenidae), long chain alkanes and alkenes were used to line the cells without further

\footnotetext{
* Correspondence and reprints

E-mail: e.d.morgan@keele.ac.uk
} 
modification (Hefetz, 1987). Butyrates, acetates and monounsaturated alcohols found in the Dufour gland secretion of Melitta (Melittidae) might be used in nest-building and interestingly, were also found in the heads of their male parasite Nomada flavopicta (Tengö and Bergström, 1976). Acetates have also been found in Melissodes desponsa (Anthophoridae), employed for the same purpose (Batra and Hefetz, 1979). For the Megachilidae the secretion seems not to be so important for the lining of the cells, since they use plant material as petals, leaves and resin besides mud and sand to build their nests (de Lello, 1971). Indeed in Trachusa byssina a derived component of Pinus was found in the lining of the nest (Cane, 1981).

The function of the gland in stingless bees is unknown. Only one report of the chemical analysis of this gland from a trigonine bee has been published (Cruz Lopez et al., 2001). In this we showed that the species Nannotrigona testaceicornis from as far apart as São Paulo in Brasil and Chiapas in México were the same chemically with respect to the contents of this gland. We report here an examination of the glands of workers from three species of Frieseomelitta, meliponine bees, from Brazil with unusually large glands. An interesting aspect of the Frieseomelitta group is the fact that they do not build cells in flat combs as most Meliponinae do, but group them in clusters. For this reason and because they possess large Dufour gland, they have been considered "primitive" stingless bees (Kerr, 1969). While workers of many Meliponini and Trigonini regularly produce trophic and reproductive eggs (trophic eggs act as a complementary item in the diet of the queen or the workers; and reproductive eggs give rise to males), the workers of Frieseomelitta species never lay eggs (Cunha and Campos, 1993).

The Frieseomelitta group is widely distributed from the Central and Southeastern areas of Brazil to southern Mexico. It belongs to the Tetragona-Tetragonisca complex, centered in the shield of Guianas-North of Brazil (Camargo and Pedro, 1992). Frieseomelitta silvestrii collected in Goiás near Brasilia can thrive reasonably well in wooden man-made boxes in the northern area of the State of São Paulo (Nogueira Neto, 1997). F. silvestrii languida has been described as a subspecies, for want of more proof that it is a separate species (Moure, personal communication). It is found only in the central Cerrado area of the State of Minas Gerais (Moure, 1989). This subspecies is characteristically larger, has relatively short hairs and fewer yellow markings than $F$. silvestrii. By appearance it may be mistaken for $F$. silvestrii but its geographical distribution is different. $F$. varia is very different from $F$. silvestrii; it is yellowish and widely distributed in Brazil, occurring from the State of Rio Grande do Norte to the northern region of the State of São Paulo.

The Dufour glands of Frieseomelitta varia, $F$. silvestrii and $F$. s. languida foraging workers are long ribbon-like structure, taking the shape of the letter U (Patricio, 1995). The secretion is stored in a gland reservoir lined with a columnar epithelium of type I cells (Noirot and Quennedey, 1974) and is discharged to the exterior through a glandular duct (Patricio, 1995). For the honeybee, it has been suggested that the hydrocarbons of the secretion are not actually produced in the gland but in the fat body (Katzav-Gozansky et al., 2000).

A compilation of the volatile compounds from the heads of a number of stingless bees, containing three species of Frieseomelitta, among them $F$. s. languida, has been published (Francke et al., 2000) but there are no reports of analyses of secretion of Dufour glands. Descriptions of the cephalic secretions of $F$. silvestrii and $F$. varia (Cruz López et al., 2002) and F. silvestrii languida (Francke et al., 2000) have been published, and preliminary studies by electroantennography have been made with the head extracts of $F$. silvestrii and $F$. varia and some substances found in those extracts (Cruz López et al., 2002). The plant resins (cerumen) carried on the corbicula of the hind tibia of these three species have also been analysed (Patricio et al., 2002). Simple electroantennographic studies have also been performed upon abdominal, leg and cerumen extracts, geranyl farnesol, and some of the pure substances found in the cerumen (unpublished). We also provide further chemical evidence for the differences between $F$. silvestrii and $F$. silvestrii languida. 


\section{MATERIALS AND METHODS}

\subsection{Insects}

Samples of $F$. varia Lepeletier 1836 and $F$. silvestrii Friese 1902 were provided from the Laboratório de Abelhas, Instituto de Biociências, Universidade de São Paulo, Brasil and from Prof. Paulo Nogueira Neto's collections; F. s. languida Moure 1989 was provided by Prof. Marina Staurengo da Cunha (Instituto de Biociências, Rio Claro SP, Brasil). F. varia Lepeletier were originally collected at Riberão Preto in northern São Paulo State, $F$. silvestrii came originally from Luiziania in Goiás State, near Brasilia. F. silvestrii languida came from the central Cerrado area in Minas Gerais State. Unless otherwise stated, mature foraging workers, collected as they arrived at the hive entrance, were taken for analysis.

\subsection{Preparation of samples for analysis}

Individual workers of each species were cooled in a refrigerator. Dissections were then carried out under a Vicker MG3 Zoomax binocular microscope with two pairs of fine forceps. Individual Dufour glands were dissected under distilled water and placed in thin-walled soft glass tubes $(1.8 \mathrm{~mm} \times$ $20 \mathrm{~mm}$ ) previously sealed at one end and the open end was then sealed in a micro-flame (Morgan, 1990).

\subsection{Chemical analysis}

Gas chromatography-mass spectrometry was carried out on a Hewlett Packard 5890 gas chromatograph coupled to a 5070B Mass Selective Detector. The operation parameters were controlled by a HP series 200 computer with HP5970C chemstation software. The chromatographic column for the analysis was a fused silica capillary column $(12 \mathrm{~m} \times$ $0.22 \mathrm{~mm}$ i.d.) coated with immobilized polydimethylsiloxane (SGE, Milton Keynes, UK). The carrier gas used was helium at a flow rate of $1 \mathrm{ml} \cdot \mathrm{min}^{-1}$. The glass capillaries were directly inserted into the injection area, heated and crushed as described by Morgan (1990). The column was maintained at $30{ }^{\circ} \mathrm{C}$ for $2 \mathrm{~min}$ after injection of the sample and then heated at $8^{\circ} \mathrm{C} \mathrm{min}-1$ to $250{ }^{\circ} \mathrm{C}$. The injector port was kept at $200^{\circ} \mathrm{C}$.

Identification of the substances was confirmed where possible by comparison of the mass spectra and retention time with those of synthetic samples. Geranylfarnesol was kindly provided by $\mathrm{C}$. Mansfield, International Flavours and Fragrances Ltd. Geranyl palmitoleate and geranyl oleate were prepared in the laboratory from palmitoleyl chloride and oleyl chloride with geraniol as described by Attygalle and Morgan (1986). Octadecyl acetate was identified by comparison of the mass spectrum with that of a sample prepared in the laboratory, eicosen-1-ol was compared with samples of both $(E)$ - and (Z)-11-eicosen-1-ol, provided by J.O. Schmidt, (Z)-11-octadecenal was prepared by pyridinium chlorochromate oxidation of commercial (Z)-11-octadecen-1-ol; linear alkanes, 1-alkanols and 2-alkanones were available commercially. Quantification was by comparison with an injection of a known amount of the same or a similar compound.

\section{RESULTS}

\subsection{Contents of glands}

The Dufour glands of $F$. varia foraging workers contained a mixture of oxygenated compounds, alcohols, aldehydes, ketones and acetates, of relatively constant composition, and one hydrocarbon (Tab. I). Compounds that were identified from their mass spectra and confirmed by comparison with retention times and mass spectra of authentic samples

Table I. The contents of the Dufour glands of workers of Frieseomelitta varia $(N=5)$. * Indicates compounds where identification has been confirmed by comparison with synthetic compounds.

\begin{tabular}{llccc}
\hline \multirow{2}{*}{ Compound } & \multicolumn{3}{c}{ Mean amount } \\
\cline { 2 - 5 } & & ng/bee & \pm SD & $\%$ \\
\hline 1 & 2-Tridecanone* & 4.6 & 0.29 & 1.02 \\
2 & 2-Pentadecanone* & 87.4 & 8.95 & 19.3 \\
3 & 2-Heptadecanone* & 16.6 & 1.59 & 3.66 \\
4 & Oleyl aldehyde* & 88.8 & 4.02 & 19.6 \\
5 & Unknown & 2.2 & 0.38 & 0.48 \\
6 & Oleyl alcohol* & 22.6 & 2.67 & 4.98 \\
7 & Nonadecenal (?) & 5.3 & 0.51 & 1.16 \\
8 & Oleyl acetate* & 3.9 & 1.4 & 0.85 \\
9 & Eicosenal* & 98.8 & 2.2 & 21.8 \\
10 & Eicosen-1-ol* & 96.5 & 9.59 & 21.3 \\
11 & Eicosen-1-yl acetate & 2.5 & 0.78 & 0.55 \\
12 & Docosane* & 11.3 & 2.48 & 2.50 \\
& Mean amount (ng) & 453 & 212 & $\dagger$ \\
\hline
\end{tabular}

$\dagger$ Minor components account for $2.86 \%$. 
Table II. Compounds identified in the Dufour gland secretion of Frieseomelitta silvestrii $(N=5)$. * Indicates compounds where identification has been confirmed by comparison with synthetic compounds, $\mathrm{t}$ indicates trace component, less than $1 \%$ of total.

\begin{tabular}{llccc}
\hline \multirow{2}{*}{ Compound } & \multicolumn{3}{c}{ Mean amount } \\
\cline { 2 - 5 } & & $\mathrm{ng} / \mathrm{bee}$ & $\pm \mathrm{SD}$ & $\%$ \\
\hline 1 & Tetradecanal* & $\mathrm{t}$ & - & \\
2 & Heptadecanal* & $\mathrm{t}$ & - & \\
3 & Nonadecanal & 24 & 2.4 & 9.6 \\
4 & Heneicosane* & 14 & 1.8 & 5.6 \\
5 & Tricosene* & 14 & 1.2 & 5.6 \\
6 & Tricosane* & 7 & 1.0 & 2.8 \\
7 & Pentacosene & 159 & 6.4 & 63.6 \\
8 & Pentacosane* & $\mathrm{t}$ & - & \\
9 & Geranylfarnesol* & $\mathrm{t}$ & - & \\
10 & Heptacosene & 23 & 1.1 & 9.2 \\
& Geranyl & & & \\
11 & palmitoleate* & $\mathrm{t}$ & - & \\
12 & An isomer & & & \\
& of $\mathrm{C}_{30} \mathrm{H}_{48}$ & $\mathrm{t}$ & - & \\
13 & An isomer & & & \\
& of $\mathrm{C}_{30} \mathrm{H}_{48}$ & $\mathrm{t}$ & - & \\
14 & Geranyl oleate* & $\mathrm{t}$ & - & \\
& Total amount (ng $)$ & 230 & 12.1 & $\dagger$ \\
\hline
\end{tabular}

$\dagger$ Minor components together equal 3.6\%.

are so marked in the table. Insufficient material was available to determine double-bond positions by the dimethyl disulphide method. The major components were eicosenal and eicosen-1-ol, confirmed with authentic samples of (Z)-11-eicosenal and (Z)-11-eicosen-1ol. In decreasing order of quantity were 2 -pentadecanone and 9-octadecenal. In the first sample of $F$. varia, from another nest, not fully quantified because the bees were of mixed ages, 2-hexadecanone was the major component in some individuals, in others it was octadecenal (oleyl aldehyde) and still others octadecenyl acetate (oleyl acetate). These latter results have not been tabulated. While the mass spectra and retention times matched, total proof of the double bond position in the eicosenyl and octadecyl compounds has not been obtained.
The average contents of individually analysed Dufour glands of $F$. silvestrii workers are listed in Table II. The gland secretion of this species is composed mainly of a mixture of unsaturated and saturated hydrocarbons, from heneicosane to nonacosane. The alkenes were identified by their mass spectra and relative retention times, since they elute just before the corresponding alkanes. Pentacosene is the major component. In some samples a small amount of tetradecanal, geranyl palmitoleate and geranyl oleate were found and in one sample a large amount of geranylfarnesol was detected. Compounds 12 and 13 in Table II have the mass spectra of linear terpenes (like the lower homologues farnesene and springene), and appear to be two isomers of the unknown compound $3,7,11,15,19,23$ hexamethyltetracosaheptaene $\left(\mathrm{C}_{30} \mathrm{H}_{48}\right)$ but not squalene, which appears at slightly longer retention. The Dufour glands of young workers of $F$. silvestrii contained the same hydrocarbons and some geranylfarnesol, but in much smaller quantity and different proportions compared with those of foraging workers.

F. s. languida Dufour glands contained a more complex mixture of hydrocarbons and oxygenated compounds than either of the other two species. Although the proportions varied widely, as shown by the standard deviations (Tab. III), the qualitative composition did not vary much. Geranylfarnesol and 1-tetradecanol were the major substances. The identification of compounds was by comparison with a mass spectral library (NIST, 2001) and approximate knowledge of the appropriate retention times, confirmed for some substances by comparison with authentic specimens.

\section{DISCUSSION}

The only previously published analysis of the Dufour gland secretion from stingless bees is our analysis of the trigonine bee Nannotrigona testaceicornis (Cruz López et al., 2001), which showed a much more complex mixture of oxygenated substances and terpenoids, but with geranylgeranyl acetate as by far the major substance. In Frieseomelitta species the mixtures are much simpler, but with the addition 
Table III. Compounds identified in the Dufour gland secretion of Frieseomelitta silvestrii languida $(N=5)$. * Indicates compounds where identification has been confirmed by comparison with synthetic compounds, $t$ indicates trace component, less than $0.5 \%$ of total.

\begin{tabular}{|c|c|c|c|c|}
\hline & \multirow{2}{*}{ Compound } & \multicolumn{3}{|c|}{ Mean amount } \\
\hline & & ng/bee & $\pm \mathrm{SD}$ & $\%$ \\
\hline 1 & Pentadecane* & 27 & 8.2 & 1.4 \\
\hline 2 & Tetradecanal* & 272 & 6.0 & 14.3 \\
\hline 3 & 1-Tetradecanol* & 307 & 182 & 16.2 \\
\hline 4 & Heptadecene & $\mathrm{t}$ & - & \\
\hline 5 & Heptadecane* & 18 & 5.6 & 0.95 \\
\hline 6 & Hexadecanal & 203 & 101 & 10.7 \\
\hline 7 & 1-Hexadecanol* & $\mathrm{t}$ & - & \\
\hline 8 & 2-Heptadecenone & $\mathrm{t}$ & - & \\
\hline 9 & 2-Heptadecanone & $\mathrm{t}$ & - & \\
\hline 10 & Nonadecene & 109 & 62.4 & 5.8 \\
\hline 11 & Nonadecane* & 181 & 76.7 & 9.6 \\
\hline 12 & Unidentified & $\mathrm{t}$ & - & \\
\hline 13 & Nonadecanal & $\mathrm{t}$ & - & \\
\hline 14 & Eicosane* & $\mathrm{t}$ & - & \\
\hline 15 & Heneicosane & 165 & 147 & 8.7 \\
\hline 16 & Tricosene* & 70 & 78 & 3.7 \\
\hline 17 & Tricosane* & $\mathrm{t}$ & - & \\
\hline 8 & Pentacosene & 117 & 130 & 6.2 \\
\hline 19 & Pentacosane* & $\mathrm{t}$ & - & \\
\hline 20 & Geranylfarnesol* & 358 & 192 & 18.9 \\
\hline 21 & Heptacosene & $\mathrm{t}$ & - & \\
\hline 22 & Geranyl palmitoleate* & 37 & 33 & 2.0 \\
\hline 23 & Geranyl oleate* & 21 & 11 & 1.1 \\
\hline 24 & Unidentified aldehyde & $\mathrm{t}$ & - & \\
\hline \multirow[t]{2}{*}{25} & Branched hydrocarbon & $\mathrm{t}$ & - & \\
\hline & Mean total amount (ng) & 1875 & 1034 & \\
\hline
\end{tabular}

of hydrocarbons. The compounds are of similar type, that is, oxygenated compounds in all three species and terpenes in $F$. sylvestrii and $F$. s. languida. There was some similarity between the secretions of $F$. silvestrii and $F$. s. languida in that both contained a number of hydrocarbons, aldehydes and geranyl esters of oleic and palmitoleic acids but, while geranylfarnesol is the major substance in $F$. $s$. languida, it was only a trace compound in $F$. silvestrii. These differences suggest a real species difference between $F$. silvestrii and $F$. s. languida. The glands of Nannotrigona testaceicornis were much larger, with about $5 \mu \mathrm{g}$ of secretion (Cruz López et al., 2001), compared with $1.8 \mu \mathrm{g}$ in $F$. s. languida, $230 \mathrm{ng}$ in $F$. sylvestrii, and slightly more in $F$. varia. Nevertheless, the glands of $F$. s. languida, with nearly $2 \mu \mathrm{g}$ of liquid in them, are large compared to those of many hymenopteran workers.

The saturated and unsaturated hydrocarbons are frequently found in the Dufour glands of bees and ants (Blum, 1981; Hefetz et al., 1986; Tengö et al., 1991; Oldham et al., 1994). Some of the oxygenated compounds too are found in other Hymenoptera (Blum, 1981; Wheeler and Duffield, 1985). It is noteworthy that 11-eicosen-1-ol is also found in the venom apparatus of Apis species (Schmidt et al., 1997), and 9-octadecen-1-ol and 9-octadecen1 -yl acetate have been reported in the labial glands of males of Bombus muscorum (Kullenberg et al., 1970). This is the first time that geranylfarnesol, geranyl oleate and geranyl palmitoleate have been found in the glandular secretions of bees, but geranylfarnesol has been earlier discovered in the wax of the insect Ceroplastes albolineatus (Rios and Perez, 1969).

\section{ACKNOWLEDGEMENTS}

We thank Professor Paulo Nogueira Neto, Universidade de São Paulo for the colonies of $F$. varia and $F$. silvestrii, Prof. Marina Staurengo da Cunha, for the F. s. languida and Prof. J.S. Moure (Universidade Federal do Paraná, Curitiba, Brasil), for the identification of the species. This work was partly supported by CAPES, Brazil, through a research studentship to EFLRAP, and by CONACYT México, through a studentship to LCL and partly through the research network "Social Evolution" of seven European universities financed by the European Commission via the Training and Mobility of Researchers (TMR) programme (Contract ERBFMRXCT 960072). We thank C. Mansfield, International Flavours and Fragrances Ltd. for the sample of geranylfarnesol, and J.O. Schmidt, Carl Hayden Bee Research Center, Tucson, USA for the eicosenol. 
Résumé - Sécrétions des abeilles sans aiguillon : les glandes de Dufour de certaines espèces de Frieseomelitta (Apidae, Meliponinae). On considère que la glande de Dufour, glande exocrine de l'appareil venimeux, est présente chez toutes les femelles et les ouvrières des Hyménoptères Aculéates, mais elle a été peu étudiée chez les abeilles sans aiguillon (Hymenoptera, Apidae, Meliponinae) et la nature de la sécrétion n'a jamais été examinée. Les abeilles sans aiguillon se répartissent en deux groupes: les Trigonini et les Meliponini. Nous avons récemment publié la première analyse de la sécrétion de la glande de Dufour d'une espèce de trigone et nous poursuivons cette étude sur trois espèces de mélipones. Bien que les trois espèces appartiennent au même genre, Frieseomelitta, leurs sécrétions sont bien différentes (Tab. I à III). $F$. varia renferme du 2-pentadecanone et ses homologues en $\mathrm{C}_{13}$ et $\mathrm{C}_{17}$, l'aldéhyde, l'alcool et l'acétate d'oleyle et les trois composés correspondants en $\mathrm{C}_{20}$ : l'éicosénal, l'éicosénol et l'acétate d'éicosényle. On trouve aussi un peu de docosane et d'autres composés mineurs. Chez $F$. silvestrii la sécrétion comporte principalement des hydrocarbures en $\mathrm{C}_{21}$ à $\mathrm{C}_{27}$, avec des traces d'aldéhydes, de géranylfarnésol, d'esters de géranyle d'acides gras et un composé inconnu $\mathrm{C}_{30} \mathrm{H}_{48}$. F . silvestrii languida possède les plus grosses glandes et le mélange le plus riche avec des hydrocarbures en $\mathrm{C}_{21}$ à $\mathrm{C}_{27}$, du 1-tetradécanole, du géranylfarnésol et les mêmes esters de géranyle. La composition des sécrétions de la glande de Dufour spécifique de chacune de ces trois espèces de Frieseomelitta suggère qu'elles peuvent avoir une fonction de phéromone pour la colonie et rend nécessaires des études comportementales.

Frieseomelitta sylvestrii / Frieseomelitta sylvestrii languida / Frieseomelitta varia / geranylfarnesol / glande de Dufour

\footnotetext{
Zusammenfassung - Sekrete von Stachellosen Bienen: Dufour Drüsen bei einige Arten von Frieseomelitta (Apidae, Meliponinae). Die Dufour Drüse ist eine exokrine Drüse am Stachelapparat, von der angenommen wird dass sie bei allen Weibchen und Arbeiterinnen der aculeaten Hymenoptera vorhanden ist. Diese wurde bei Stachellosen Bienen (Hymenoptera: Apidae: Meliponinae) bisher wenig untersucht. Bisher ist über die Zusammensetzung des Sekretes noch nichts bekannt. Die Stachellosen Bienen sind in 2 Stämme unterteilt, in Trigonini und Meliponini. Wir haben kürzlich über die ersten Analysen von Dufour Drüsensekreten von einigen Arten der Trigonen berichtet, hier beschreiben wir diese für drei Arten der Meliponinen. Obwohl sie zurselben Gattung gehören, waren die Sekrete sehr unterschiedlich (Tab. I bis III). Frieseomelitta varia enthält 2-Pentadecanon und seine $\mathrm{C}_{13}$ und $\mathrm{C}_{17}$ Homologe, Oleyl Aldehyd, Alkohol und Acetat und 3 sich entsprechenden $\mathrm{C}_{20}$ Verbindungen: Eicosenal, Eicosenol
}

und Eicosenyl Acetat. Es gab geringen Mengen von Docosan und anderen untergeordneten Komponenten. In F. silvestrii bestand das Sekret hauptsächlich aus den Kohlenwasserstoffen $\mathrm{C}_{21}$ bis $\mathrm{C}_{27}$, mit Spuren von Aldehyden, Geranylfarnesol, Geranyl Estern mit Fettsäuren und einer unbekannten Verbindung $\mathrm{C}_{30} \mathrm{H}_{48} . F$. silvestrii languida hatte die größten Drüsen und die reichhaltigste Mischung aus Kohlenwasserstoffen von $\mathrm{C}_{15}$ bis $\mathrm{C}_{27}, 1$-Tetradecanol, Geranylfarnesol und den gleichen Geranyl Ester. Der artspezifische Gehalt der Dufour Drüsen dieser 3 Arten lässt vermuten, dass sie auch eine Pheromonfunktion im Volk haben könnten und macht Verhaltensuntersuchungen notwendig.

Frieseomelitta sylvestrii / Frieseomelitta varia / Frieseomelitta sylvestrii languida / Geranylfarnesol / Dufour Drüse

\section{REFERENCES}

Attygalle A.B., Morgan E.D. (1986) Versatile microreactor and extractor, Anal. Chem. 58, 3054-3058.

Batra S.W.T., Hefetz A. (1979) Chemistry of the cephalic and Dufour's secretions of Melissodes bees, Ann. Entomol. Soc. Am. 72, 514-515.

Bergström G., Tengö J. (1974) Studies on natural odoriferous compounds. IX. Farnesyl, geranyl esters as main volatile constituents of secretion from Dufour's gland in six species of Andrena (Hymenoptera: Apidae), Chem. Scr. 5, 28-38.

Blum M.S. (1981) Chemical defences of Arthropods, Academic Press, New York, London, 652 p.

Camargo J.M.F., Pedro S.R.M. (1992) Systematics, phylogeny and biogeography of the Meliponinae (Hymenoptera: Apidae): a mini-review, Apidologie 23, 509-522.

Cane J.H. (1981) Dufour's gland secretion in the cell linings of bees (Hymenoptera: Apoidea), J. Chem. Ecol. 7, 403-410.

Cruz López L., Patricio E.F.L.R.A., Morgan E.D. (2001) Secretions of stingless bees: the Dufour gland of Nannotrigona testaceicornis, J. Chem. Ecol. 27, 69-80.

Cruz López L., Patricio E.F.L.R.A., Maile R., Morgan E.D. (2002) Secretions of stingless bees: cephalic secretions of two Frieseomelitta species, J. Insect Physiol. 48, 453-458.

Cunha M.A.S., Campos J.L.O. (1993) Desenvolvimento ovariano em operárias de Frieseomelitta varia (Lep. 1836) (Hymenoptera: Apidae), Rev. Brasil. Biol. 53, 63-69.

Francke W., Lübke G., Schröder W., Reckziegel A., Imperatriz-Fonseca V., Kleinert A., Engels E., Hartfelder K., Radtke R., Engels W. (2000) Identification of oxygen containing volatiles in cephalic secretions of workers of Brazilian stingless bees, J. Brazil. Chem. Soc. 11, 562571. 
Hefetz A. (1987) The role of Dufour's gland secretions in bees, Physiol. Entomol. 12, 243253.

Hefetz A., Bergström G., Tengö J. (1986) Species, individual and kin-specific blends in Dufour's gland secretion of halictine bees: chemical evidence, J. Chem. Ecol. 12, 197-208.

Hefetz A., Blum M.S., Eickwort G.C., Wheeler J.W. (1978) Chemistry of the Dufour's gland secretion of halictine bees, Comp. Biochem. Physiol. B 61, 129-132.

Hefetz A., Fales H., Batra S.W.T. (1979) Natural polyesters: Dufour's gland macrocyclic lactones from brood cell laministers in Colletes bees, Science 204, 415-417.

Katzav-Gozansky T., Soroker V., Hefetz A. (2000) Plasticity in caste-related exocrine secretion biosynthesis in the honeybee (Apis mellifera), J. Insect Physiol. 46, 993-998.

Kerr W.E. (1969) Some aspects of the evolution of social bees, Evol. Biol. 3, 119-175.

Kerr W.E., de Lello E. (1962) Sting glands in stingless bees - a vestigial character (Hymenoptera: Apidae), J. N.Y. Entomol. Soc. 70, 190-214.

Kullenberg B., Bergström G., Ställberg-Stenhagen S. (1970) Volatile components of the marking secretion of male bumblebees, Acta Chim. Scand. 24, 1481-1483.

de Lello E. (1971) Anatomia e histologia das glândulas do ferrão das abelhas. III. (Hymenoptera: Megachilidae, Melittidae), Ciência e Cultura 23, 253-258.

de Lello E. (1976) Adnexal glands of the sting apparatus in bees: anatomy and histology. V. (Hymenoptera: Apidae), J. Kans. Entomol. Soc. 49, 85-99.

Morgan E.D. (1990) Preparation of small-scale samples of insects for chromatography, Anal. Chim. Acta 236, 227-235.

Moure J.S. (1989) Espécies novas de abelhas da região central de Minas Gerais, Brasil (Hymenoptera, Apoidea), Acta Biol. Paraná, Curitibá 18, 115-127.

NIST Library (2001) National Institute of Standards and Testing (USA), Computerized Library of mass spectra of organic compounds, Version $1.5 \mathrm{a}$.
Nogueira Neto P. (1997) Vida e Criação de Abelhas Indígenas Sem Ferrão, São Paulo, Edição Nogueirapis, $445 \mathrm{p}$.

Noirot C., Quennedey A. (1974) Fine structure of insect epidermal glands, Annu. Rev. Entomol. 19, 61-80.

Oldham N.J., Morgan E.D., Billen J. (1994) On the similarity of the Dufour gland secretion and the cuticular hydrocarbons of some bumblebees, Physiol. Entomol. 19, 115-123.

Patricio E.F.L.R.A. (1995) Glandulas de Dufour em Abelhas sem Ferrão, Ph.D. Thesis, Instituto de Biociências, Universidade Estadual Paulista "Julio de Mesquita Filho", Rio Claro, SP, Brasil.

Patricio E.F.L.R.A., Cruz López L., Maile R., Tentschert J., Jones G.R, Morgan E.D. (2002) The propolis of stingless bees: terpenes from the tibia of three Frieseomelitta species, J. Insect Physiol. 48, 249-254.

Rios T., Perez C.S. (1969) Geranylfarnesol, a new acyclic $\mathrm{C}_{25}$ isoprenoid alcohol isolated from insect wax, J. Chem. Soc., Chem. Commun. 1969, 214-215.

Schmidt J.O., Morgan E.D., Oldham N.J., do Nascimento R.R., Dani F.R. (1997) (Z)-11Eicosen-1-ol, a major component of Apis cerana venom, J. Chem. Ecol. 23, 1929-1939.

Tengö J., Bergström G. (1975) All trans farnesyl hexanoate and geranyl octanoate in the Dufour's gland secretion of Andrena (Hymenoptera: Apoidea), J. Chem. Ecol. 1, 253268.

Tengo J., Bergström G. (1976) Odor correspondence between Melitta females and males of their nest parasite Nomada flavopicta, K. J. Chem. Ecol. 2, 57-65.

Tengö J., Hefetz A., Bertsch A., Schmitt U., Lübke G., Francke W. (1991) Species specificity and complexity of Dufour's gland secretion of bumblebees, Comp. Biochem. Physiol. B 99, 641-646.

Wheeler J.W., Duffield R.M. (1985) Pheromones of Hymenoptera and Isoptera, in: Morgan E.D., Mandava N.B. (Eds.), Handbook of Natural Pesticides, Vol. IV, Part B, CRC Press, Boca Raton, pp. 59-206. 